\title{
Amidates as Leaving Groups: Structure/Reactivity Correlation of the Hydroxide Dependent E1cB-Like Breakdown of Carbinolamides in Aqueous Solution
}

William J. Tenn III, John L. Murphy, Jessica K. Bim-Merle, Jason A. Brown, Adam J. Junia, Malea A. Price, and Richard W. Nagorski*

Department of Chemistry, Illinois State University, Normal, Illinois 61790-4160

rnagor@ilstu.edu

SUPPLEMENTAL MATERIAL

TABLE OF CONTENTS

Synthesis and Characterization of $N$-(Hydroxymethyl)benzamides: S4

References:

S6

Table 1S: Wavelengths Used for the Determination of $k_{\text {obsd }}$ by UV-Vis Spectroscopy and HPLC, and the Correction Factors Used to Adjust the Observed Areas of the Amide Reaction Product 
Table 2S: Constants for the Hydroxide-Independent Reaction of $N$-(Hydroxymethyl)benzamide and Derivatives and their $\mathrm{p} K_{\mathrm{a}}$ 's in Water as a function of Temperature, $I=1.0(\mathrm{KCl})$

Figure 1S: Plot of the effect of hydroxide concentration (M) on the observed rates of reaction ( $\left.k_{\mathrm{obsd}}, \mathrm{s}^{-1}\right)$ for 3,4-dichloro- $N$-(hydroxymethyl)benzamide in $\mathrm{H}_{2} \mathrm{O}, I=1.0(\mathrm{KCl})$, at $25^{\circ} \mathrm{C}$.

Figure 2S: Hammett plot of $\log \left(k^{\prime}{ }_{1 \mathrm{X}} / k^{\prime}{ }_{1 \mathrm{H}}\right)$ for the hydroxide independent reaction of a series of $N$-(hydroxymethyl)benzamide derivatives in $\mathrm{H}_{2} \mathrm{O}$ at $25^{\circ} \mathrm{C}, I=1.0(\mathrm{KCl})$ vs. $\sigma$.

Figure 3S: Hammett plot of $\log \left(K_{\mathrm{a}}^{\mathrm{X}} / K_{\mathrm{a}}^{\mathrm{H}}\right)$ for the hydroxyl group of a series of $\mathrm{N}$-(hydroxymethyl)benzamide derivatives in $\mathrm{H}_{2} \mathrm{O}$ at $25^{\circ} \mathrm{C}$, $I=1.0 \mathrm{M}(\mathrm{KCl})$ vs. $\sigma$.

Figure 4S: Hammett plot of $\log \left(K_{\mathrm{a}}^{\mathrm{X}} / K_{\mathrm{a}}^{\mathrm{H}}\right)$ for the hydroxyl group of a series of $N$-(hydroxymethyl)benzamide derivatives in $\mathrm{H}_{2} \mathrm{O}$ at $25^{\circ} \mathrm{C}, I=1.0$ (KCl) vs. $\sigma$ excluding $\mathbf{4 f} \& \mathbf{4 h}$.

Figure 5S: Plot of $k_{\mathrm{obsd}} v s$. total phosphate concentration for the reaction of $4 \mathrm{a}$ in $\mathrm{H}_{2} \mathrm{O}, \mathrm{pH}=11.46$, at $25^{\circ} \mathrm{C}, I=1.0 \mathrm{M}(\mathrm{KCl})$. 
Figure 6S: $\quad{ }^{1} \mathrm{H}-\mathrm{NMR}$ of 3,4-dichloro- $N$-(hydroxymethyl)benzamide in DMSO at $25^{\circ} \mathrm{C}$ using $400 \mathrm{MHz}$ spectrometer.

Figure 7S: $\quad{ }^{13} \mathrm{C}-\mathrm{NMR}$ of 3,4-dichloro- $N$-(hydroxymethyl)benzamide in DMSO at $25^{\circ} \mathrm{C}$ at $100 \mathrm{MHz}$.

Figure 8S: $\quad{ }^{1} \mathrm{H}-\mathrm{NMR}$ of 2,4-dichloro- $N$-(hydroxymethyl)benzamide in DMSO at $25^{\circ} \mathrm{C}$ using $400 \mathrm{MHz}$ spectrometer.

Figure 9S: $\quad{ }^{13} \mathrm{C}-\mathrm{NMR}$ of 2,4-dichloro- $N$-(hydroxymethyl)benzamide in DMSO at $25^{\circ} \mathrm{C}$ at $100 \mathrm{MHz}$. 


\section{Experimental:}

General: All melting points are uncorrected and were obtained using a melting point apparatus.

The ${ }^{1} \mathrm{H}-\mathrm{NMR}$ spectra reported here were obtained in $\mathrm{CDCl}_{3}(7.27 \mathrm{ppm})$ using a $400 \mathrm{MHz}$ instrument unless otherwise stated.

\section{Synthesis and Characterization of $N$-(Hydroxymethyl)benzamides:}

$N$-(hydroxymethyl)benzamide (4a): was synthesized from benzamide and formaldehyde using a published method and purified by recrystallization from ethanol. ${ }^{1}$ The melting point of 4a was $112-114{ }^{\circ} \mathrm{C}\left(\right.$ lit. $\left.\mathrm{mp}=108-110{ }^{\circ} \mathrm{C}\right) .{ }^{1}{ }^{1} \mathrm{H}-\mathrm{NMR} 400 \mathrm{MHz}\left(\mathrm{CDCl}_{3}\right) \delta 7.84(\mathrm{~d}, 2 \mathrm{H}), 7.56(\mathrm{t}$, 1H), $7.48(\mathrm{t}, 2 \mathrm{H}), 7.42-7.32(\mathrm{bs}, 1 \mathrm{H}, \mathrm{OH}), 5.01(\mathrm{t}, 2 \mathrm{H}), 4.0-3.9(\mathrm{bm}, 1 \mathrm{H})$.

4-Chloro- $N$-(hydroxymethyl)benzamide (4b): was prepared in 19\% yield as described above, from 4-chlorobenzamide and recrystallized from ethanol to produce a white crystalline solid with a melting point of $117-118{ }^{\circ} \mathrm{C}$ (lit. $\left.\mathrm{mp}=120^{\circ} \mathrm{C}\right) .{ }^{2}{ }^{1} \mathrm{H}-\mathrm{NMR} 400 \mathrm{MHz}\left(\mathrm{CDCl}_{3}\right) \delta 7.74$ (d, 2H), $7.44(\mathrm{~d}, 2 \mathrm{H}), 7.0-7.1(\mathrm{bs}, 1 \mathrm{H}, \mathrm{OH}), 4.97(\mathrm{t}, 2 \mathrm{H}), 3.38(\mathrm{t}, 1 \mathrm{H})$.

General Synthetic Procedure: The remainder of the carbinolamides were synthesized using the following general method. The substituted benzamide $(2-4 \mathrm{~g})$ was dissolved in a $\sim 40 \mathrm{~mL}$ of methanol. To this solution was added $0.5 \mathrm{~g}$ of potassium carbonate and $\sim 10 \mathrm{~g}$ of paraformaldehyde which was allowed to stir at room temperature for $24 \mathrm{hrs}$. After this time period, the progress of the reaction was determined by HPLC using an appropriate solvent system (see Table 1S). Further additions of paraformaldehyde were performed if the reaction had not proceeded to a satisfactory degree $(95-100 \%)$. Once the reaction was complete, the volume of the mixture was reduced to approximately half its original volume using a rotary evaporator, and the resulting solution was cooled to $4{ }^{\circ} \mathrm{C}$. Upon cooling, a solid material precipitates out of 
solution which largely consisted of paraformaldehyde with a small amount of product. This solid was removed by vacuum filtration with the filtrate containing the desired product. Prior to final purification, the filtrate was further reduced in volume using a rotary evaporator and this solution was added directly to the chromatography column. The column used, in all cases, was composed of silica gel with methanol used as the eluant.

3-Chloro- $N$-(hydroxymethyl)benzamide (4d): was synthesized using 3-chlorobenzamide (5d) (recrystallized from ethanol, $\mathrm{mp}=132-134{ }^{\circ} \mathrm{C}$; lit. ${ }^{3} \mathrm{mp}=134{ }^{\circ} \mathrm{C}$ ) from 3-chlorobenzoic acid produced in the same manner described for $\mathbf{5 c}$. The physical properties of $\mathbf{4 d}$; mp $123-125{ }^{\circ} \mathrm{C}$ (lit. $\left.\mathrm{mp}=125-127{ }^{\circ} \mathrm{C}\right)^{4}{ }^{1} \mathrm{H}-\mathrm{NMR} 400 \mathrm{MHz}\left(\mathrm{CDCl}_{3}\right) \delta 7.80(\mathrm{~s}, 1 \mathrm{H}), 7.66(\mathrm{~d}, 1 \mathrm{H}), 7.52(\mathrm{~m}, 1 \mathrm{H})$, $7.4(\mathrm{~m}, 1 \mathrm{H}), 7.12(\mathrm{bs}, 1 \mathrm{H}), 4.98(\mathrm{~d}, 2 \mathrm{H}), 3.5(\mathrm{bs}, 1 \mathrm{H})$.

2-Chloro- $N$-(hydroxymethyl)benzamide (4e): was synthesized using 2-chlorobenzamide (5e) (recrystallized from ethanol, mp 140-142 ${ }^{\circ} \mathrm{C}$; lit. ${ }^{3} \mathrm{mp} 142{ }^{\circ} \mathrm{C}$ ) from 2-chlorobenzoic acid as described for 5c. The physical properties of $\mathbf{4 e}$; mp 110-111 ${ }^{\circ} \mathrm{C}$ (lit. mp $\left.=106-108{ }^{\circ} \mathrm{C}\right){ }^{5}{ }^{1} \mathrm{H}-\mathrm{NMR}$ $400 \mathrm{MHz}\left(\mathrm{CDCl}_{3}\right) \delta 7.73(\mathrm{dd}, 1 \mathrm{H}), 7.35-7.45$ (m, 3H), 4.97 (dd, 2H), 3.35 (t, 1H).

4-Nitro- $N$-(hydroxymethyl)benzamide (4g): was synthesized using 4-nitrobenzamide (5g) (recrystallized from $\mathrm{H}_{2} \mathrm{O}$; mp 207-209 ${ }^{\circ} \mathrm{C}$; lit. $^{3} \mathrm{mp} 206^{\circ} \mathrm{C}$ ) from 4-nitrobenzoic acid as described for 5c. The physical properties of $\mathbf{4 g}$; mp $140-141{ }^{\circ} \mathrm{C}$ (lit. $\left.\mathrm{mp}=138-140{ }^{\circ} \mathrm{C}\right)^{5}{ }^{1} \mathrm{H}-\mathrm{NMR} 400 \mathrm{MHz}$ $\left(\mathrm{CDCl}_{3}\right) \delta 8.34(\mathrm{~d}, 2 \mathrm{H}), 7.98(\mathrm{~d}, 2 \mathrm{H}), 7.12(\mathrm{bs}, 1 \mathrm{H}, \mathrm{OH}), 5.02(\mathrm{bt}, 2 \mathrm{H}), 3.28(\mathrm{bt}, 1 \mathrm{H})$

3-Nitro- $N$-(hydroxymethyl)benzamide (4h): was synthesized using 3-nitrobenzamide (5h) (recrystallized from $\mathrm{H}_{2} \mathrm{O}$; mp $141-143{ }^{\circ} \mathrm{C}$; lit. ${ }^{3} \mathrm{mp} 141-143{ }^{\circ} \mathrm{C}$ ) from 3-nitrobenzoic acid as described for 5c. mp 140-142 ${ }^{\circ} \mathrm{C}$ (lit mp $\left.=136-139{ }^{\circ} \mathrm{C}\right)^{5}{ }^{1} \mathrm{H}-\mathrm{NMR} 400 \mathrm{MHz}\left(\mathrm{CDCl}_{3}\right) \delta 8.64(\mathrm{~m}$, 1H), 8.41 (d, 1H), 8.18 (m, 1H), 7.69 (m, 1H), 7.18 (bs, 1H, OH), 5.00 (d, 2H), 3.30 (bm, 1H). 


\section{REFERENCES}

(1) Nair, B. R.; Francis, J. D. J. Chromatogr. 1980, 195, 158-161.

(2) Johansen, M.; Bundgaard, H. Arch. Pharm. Chem. Sci. Edn. 1979, 7, 175-192.

(3) Dictionary of Organic Compounds; 6th ed.; Buckingham, J. B., Ed.; Chapman \& Hill: New York, 1996.

(4) Barlin, G. B.; Davies, L. P.; Ireland, S. J.; Ngu, M. M. L.; Zhang, J. Aust. J. Chem. 1992, 45, 731-749.

(5) Schonenberger, H.; Bindl, L.; Adam, A. Arch. Pharm. 1973, 306, 64-75. 
Table 1S: Wavelengths Used for the Determination of $k_{\text {obsd }}$ by UV-Vis Spectroscopy and HPLC, and the Correction Factors Used to Adjust the Observed Areas of the Amide Reaction Product

\begin{tabular}{cccc}
\hline Compound & $\lambda_{\mathrm{UV}}(\mathrm{nm})^{\mathrm{a}}$ & $\lambda_{\text {HPLC }}(\mathrm{nm})^{\mathrm{a}, \mathrm{b}}$ & $R_{\mathrm{x}}{ }^{\mathrm{c}}$ \\
\hline $\mathbf{4 a}$ & 227 & $254^{\mathrm{d}}$ & 1.81 \\
$\mathbf{4 b}$ & 238 & $265^{\mathrm{d}}$ & 1.73 \\
$\mathbf{4} \mathbf{c}$ & 230 & $234^{\mathrm{d}}$ & 1.43 \\
$\mathbf{4 d}$ & 240 & $240^{\mathrm{d}}$ & 1.54 \\
$\mathbf{4}$ & 224 & $230^{\mathrm{e}}$ & 1.30 \\
$\mathbf{4}$ & 290 & - & - \\
$\mathbf{4 g}^{\mathrm{f}}$ & 243 & - & -
\end{tabular}

${ }^{\mathrm{a}}$ Experiments were performed in $\mathrm{H}_{2} \mathrm{O}$ at $25 \mathrm{C}, I=1.0(\mathrm{KCl})$ with substrate concentration of $5 \mathrm{x}$ $10^{-5}-1 \times 10^{-4} \mathrm{M}{ }^{\mathrm{b}} 100 \mu \mathrm{L}$ injection into the HPLC system having a C-18 reverse-phase column. ${ }^{\mathrm{c}}$ Determined from the differences in the total area change for the carbinolamide vs. the amide over 3- 5 half-lives. ${ }^{\mathrm{d}}$ HPLC solvent system was $90 \%$ 70/30 water/methanol 10\% methanol. ${ }^{\mathrm{e}}$ HPLC solvent system was $100 \% 70 / 30$ water ${ }^{f}$ Reactions were sufficiently rapid that HPLC studies were not necessary to obtain the results presented here. 
Table 2S: Constants for the Hydroxide-Independent Reaction of $N$-(Hydroxymethyl)benzamide and Derivatives and their $\mathrm{p} K_{\mathrm{a}}$ 's in Water as a function of Temperature, $I=1.0(\mathrm{KCl})$

\begin{tabular}{|c|c|c|c|c|c|c|}
\hline Compound & Temp $\left({ }^{\circ} \mathrm{C}\right)$ & $k_{1}^{\prime}{ }^{a}\left(\mathrm{M}^{-1} \mathrm{~s}^{-1}\right)$ & $k_{1}\left(\mathrm{~s}^{-1}\right)^{\mathrm{b}, \mathrm{c}}$ & $\mathrm{p}_{\mathrm{a}}^{\mathrm{b}, \mathrm{d}}$ & $k_{\text {rel }}{ }^{\mathrm{e}}$ & $k_{1}^{\prime}\left(\mathrm{M}^{-1} \mathrm{~s}^{-1}, \mathrm{lit}\right)^{\mathrm{f}}$ \\
\hline \multirow[t]{3}{*}{$4 a$} & $25^{\mathrm{g}}$ & 0.37 & $0.042 \pm 0.003$ & $13.05 \pm 0.05$ & 1 & 1.83 \\
\hline & 20 & - & $0.019 \pm 0.005$ & $12.85 \pm 0.1$ & - & - \\
\hline & 15 & - & $0.013 \pm 0.003$ & $13.04 \pm 0.05$ & - & - \\
\hline \multirow[t]{3}{*}{$4 b$} & $25^{g}$ & 0.62 & $0.068 \pm 0.005$ & $13.04 \pm 0.05$ & 1.6 & 3.67 \\
\hline & 20 & - & $0.040 \pm 0.003$ & $13.09 \pm 0.05$ & - & - \\
\hline & 15 & - & $0.020 \pm 0.003$ & $13.02 \pm 0.05$ & - & - \\
\hline \multirow[t]{3}{*}{$4 c$} & $25^{\mathrm{g}}$ & 1.73 & $0.19 \pm 0.01$ & $13.04 \pm 0.05$ & 4.5 & - \\
\hline & 20 & - & $0.094 \pm 0.007$ & $13.06 \pm 0.07$ & - & - \\
\hline & 15 & - & $0.057 \pm 0.005$ & $13.12 \pm 0.07$ & - & - \\
\hline \multirow{3}{*}{$4 h$} & 25 & 1.30 & $0.13 \pm 0.009$ & $13.00 \pm 0.05$ & 3.1 & 12.33 \\
\hline & 20 & - & $0.068 \pm 0.007$ & $12.90 \pm 0.08$ & - & - \\
\hline & 15 & - & $0.039 \pm 0.006$ & $12.90 \pm 0.05$ & - & - \\
\hline
\end{tabular}

\footnotetext{
${ }^{a}$ Apparent second-order rate constant for the hydroxide-dependent breakdown of the carbinolamides in water calculated from $k_{1}$ and $K_{\mathrm{a}}$ using $k^{\prime}{ }_{1}=\left(k_{1} K_{\mathrm{a}}\right) / K_{\mathrm{w}}$ and $K_{\mathrm{w}}=1 \times 10^{-14} \mathrm{M}^{2}$. ${ }^{\mathrm{b}}$ Errors obtained from nonlinear least-squares fits of $k_{\text {obsd }} \mathrm{Vs}$. [HO'] according to equation 3 . $^{\mathrm{c}}$ First-order rate constant for the $\mathrm{pH}$-independent breakdown of the deprotonated carbinolamide. ${ }^{\mathrm{d}}$ Ionization constant for the hydroxyl group of the carbinolamide. ${ }^{\mathrm{e}}$ Calculated by dividing $k_{1}$ for 4a into the $k_{1}$ value for each amide. ${ }^{\mathrm{f}} k^{\prime}{ }_{1}$ values obtained from ref 2 and were determined in $\mathrm{H}_{2} \mathrm{O}$ at $37^{\circ} \mathrm{C}, I=0.5 .{ }^{\mathrm{g}}$ Previously reported in ref 33 .
} 


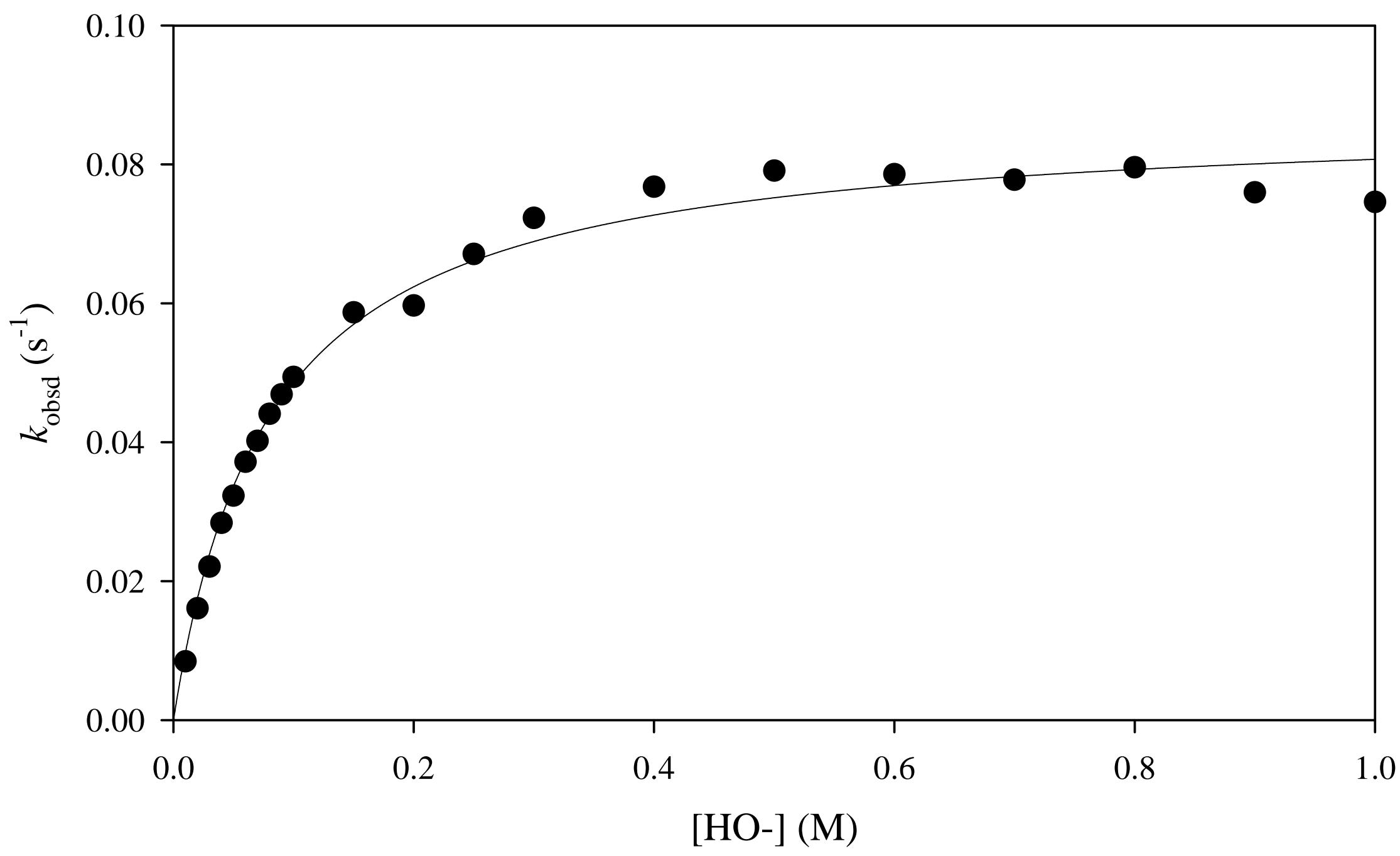

Figure 1S: Plot of the effect of hydroxide concentration $(\mathrm{M})$ on the observed rates of reaction $\left(k_{\text {obsd }}, \mathrm{s}^{-1}\right)$ for 3,4-dichloro- $N$ (hydroxymethyl)benzamide in $\mathrm{H}_{2} \mathrm{O}, I=1.0(\mathrm{KCl})$, at $25^{\circ} \mathrm{C}$. 


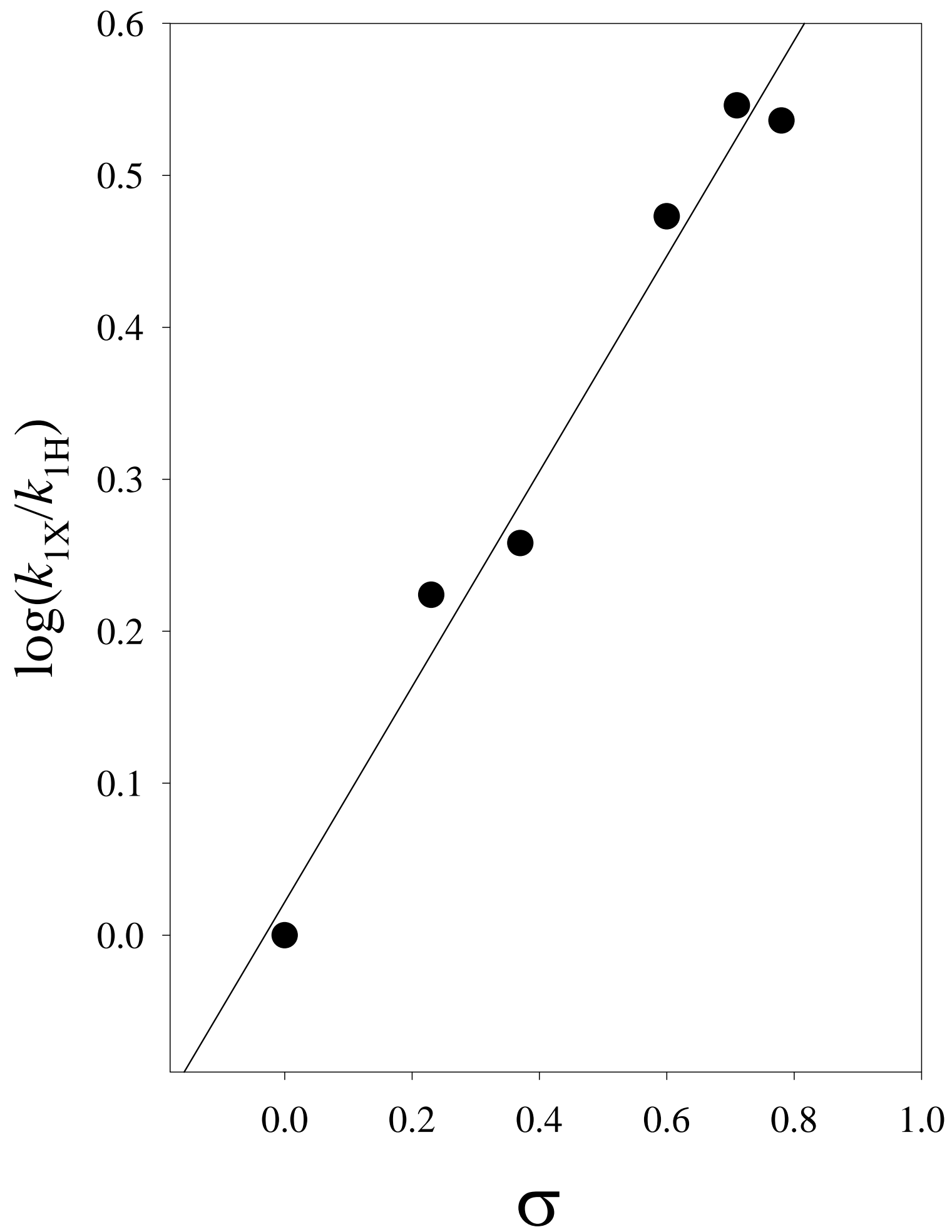

Figure 2S: Hammett plot of $\log \left(k^{\prime}{ }_{1 \mathrm{X}} / k^{\prime}{ }_{1 \mathrm{H}}\right)$ for the hydroxide independent reaction of a series of $N$-(hydroxymethyl)benzamide derivatives in $\mathrm{H}_{2} \mathrm{O}$ at $25^{\circ} \mathrm{C}, I=1.0(\mathrm{KCl})$ vs. $\sigma$. 


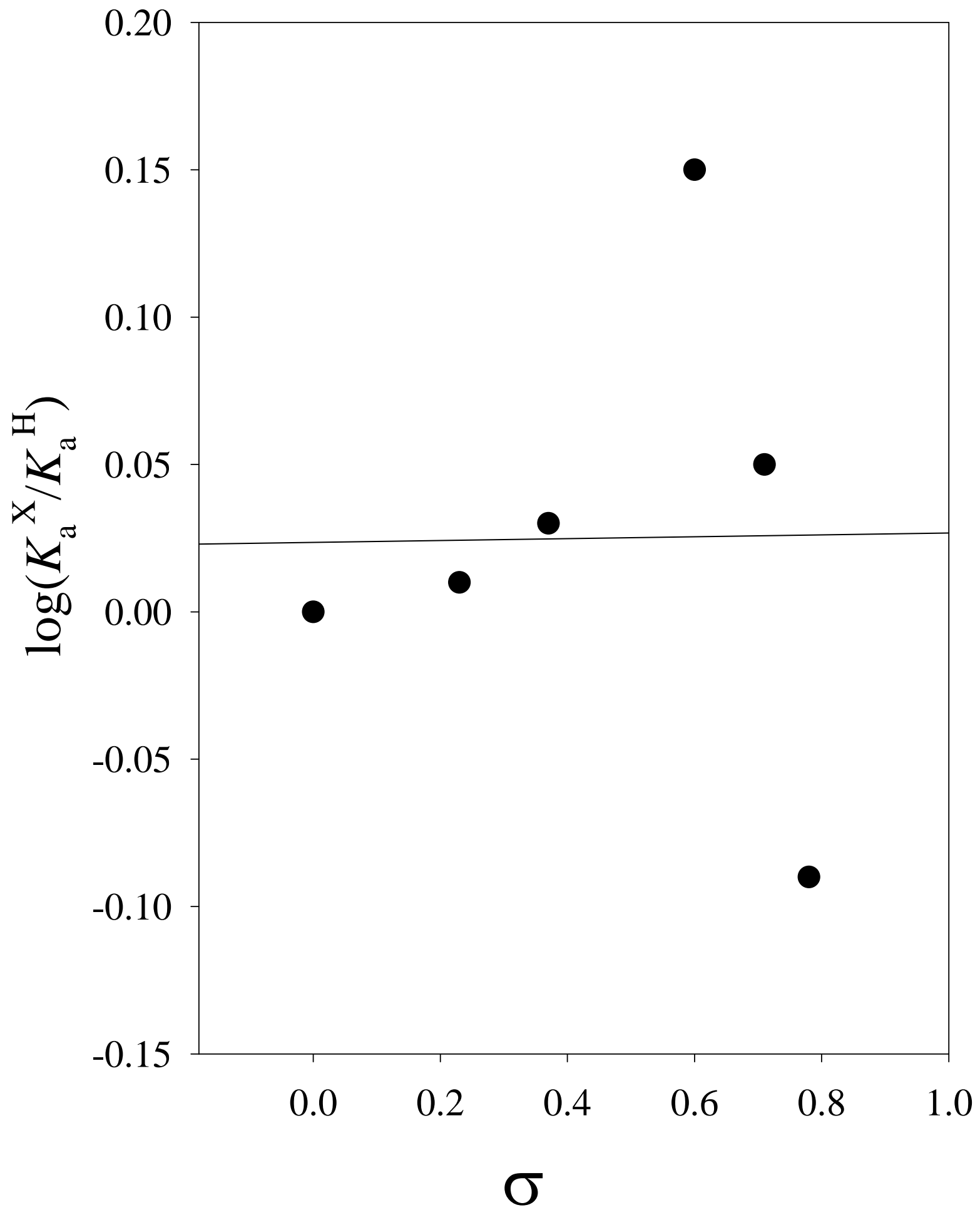

Figure 3S: Hammett plot of $\log \left(K_{\mathrm{a}}^{\mathrm{X}} / K_{\mathrm{a}}{ }^{\mathrm{H}}\right)$ for the hydroxyl group of a series of $N$ (hydroxymethyl)benzamide derivatives in $\mathrm{H}_{2} \mathrm{O}$ at $25^{\circ} \mathrm{C}, I=1.0 \mathrm{M}(\mathrm{KCl})$ vs. $\sigma$. 


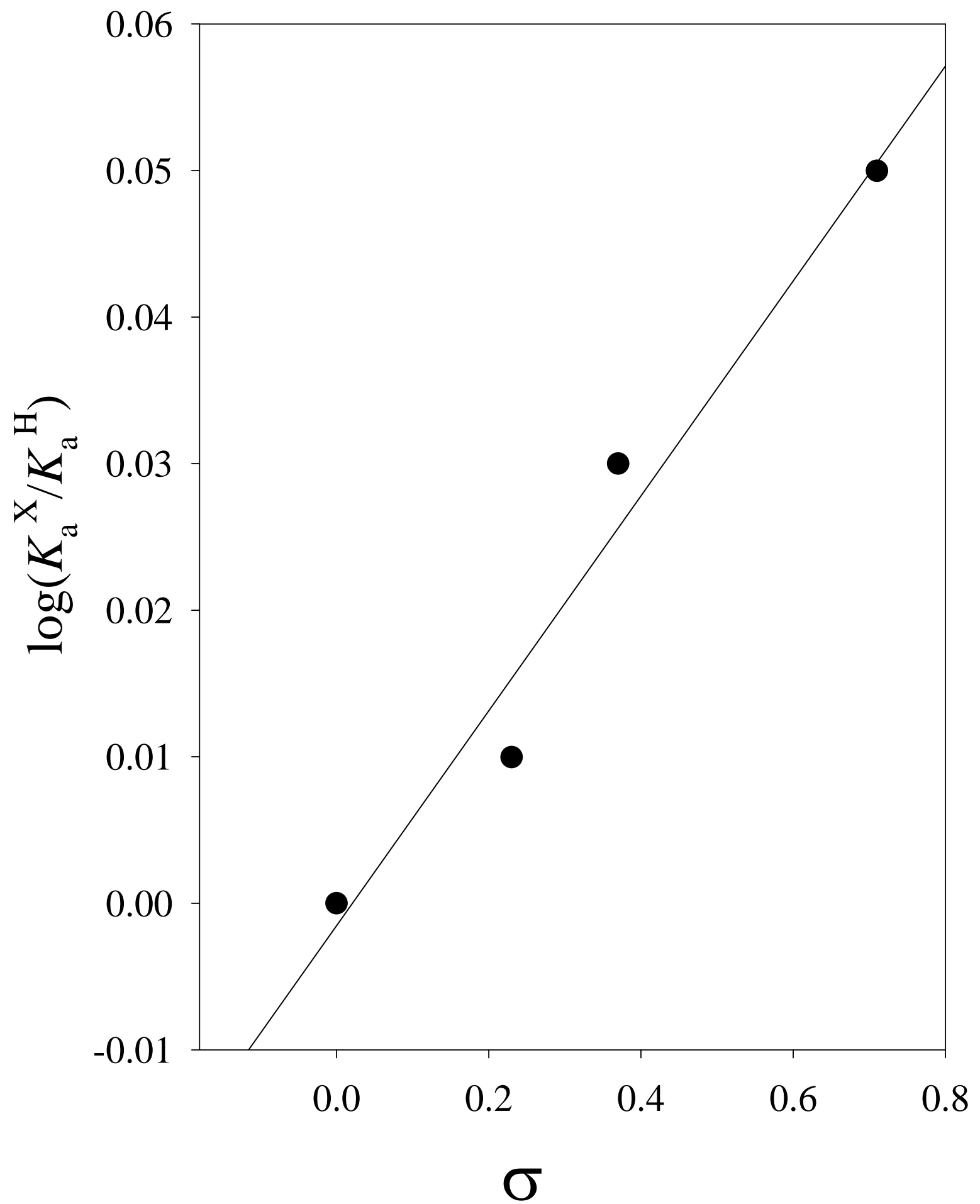

Figure 4S: Hammett plot of $\log \left(K_{\mathrm{a}}^{\mathrm{X}} / K_{\mathrm{a}}{ }^{\mathrm{H}}\right)$ for the hydroxyl group of a series of $N$ (hydroxymethyl)benzamide derivatives in $\mathrm{H}_{2} \mathrm{O}$ at $25^{\circ} \mathrm{C}, I=1.0(\mathrm{KCl})$ vs. $\sigma$ excluding $\mathbf{4 f} \& \mathbf{4 h}$. 


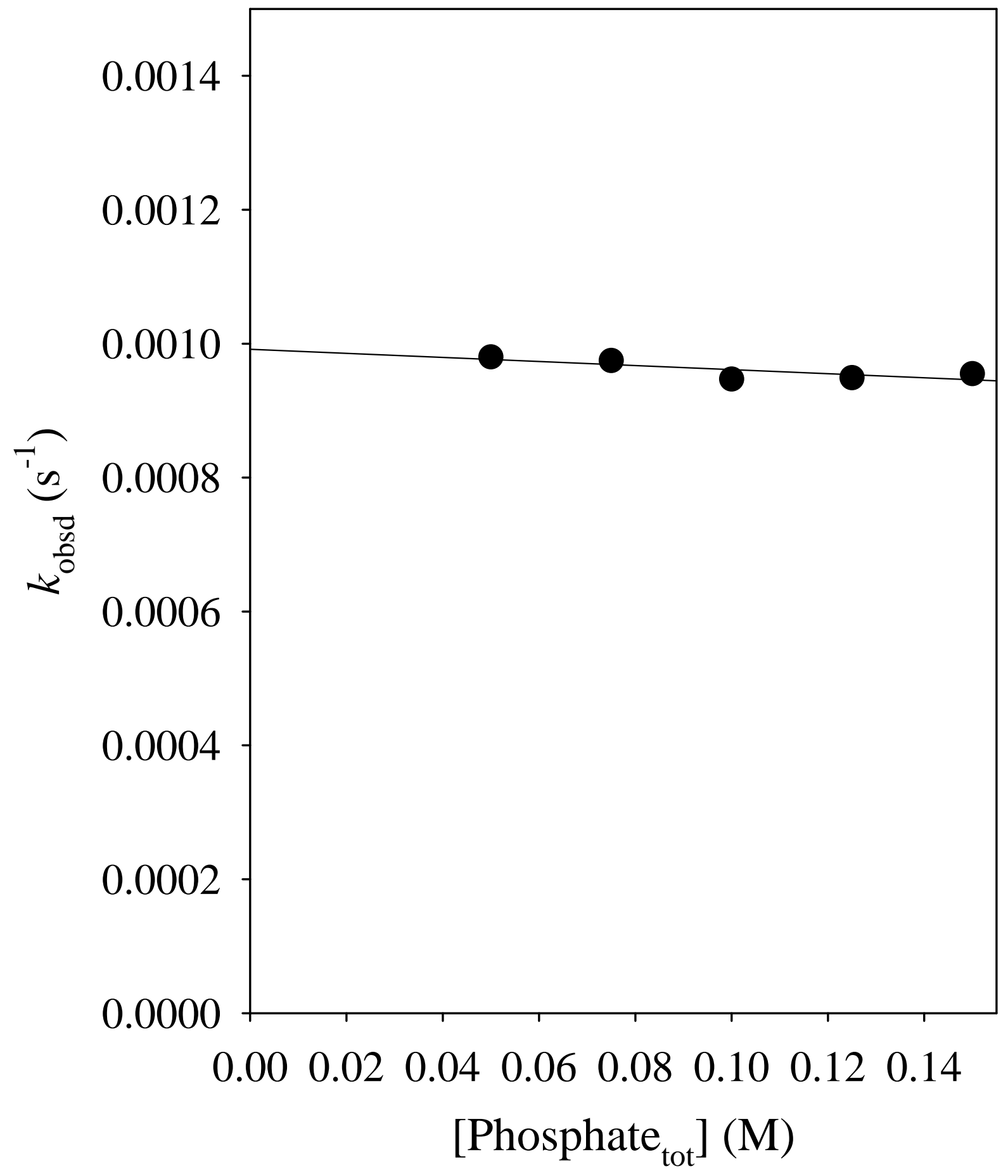

Figure 5S: Plot of $k_{\text {obsd }} v s$. total phosphate concentration for the reaction of $4 \mathrm{a}$ in $\mathrm{H}_{2} \mathrm{O}, \mathrm{pH}=$ 11.46, at $25^{\circ} \mathrm{C}, I=1.0 \mathrm{M}(\mathrm{KCl})$. 


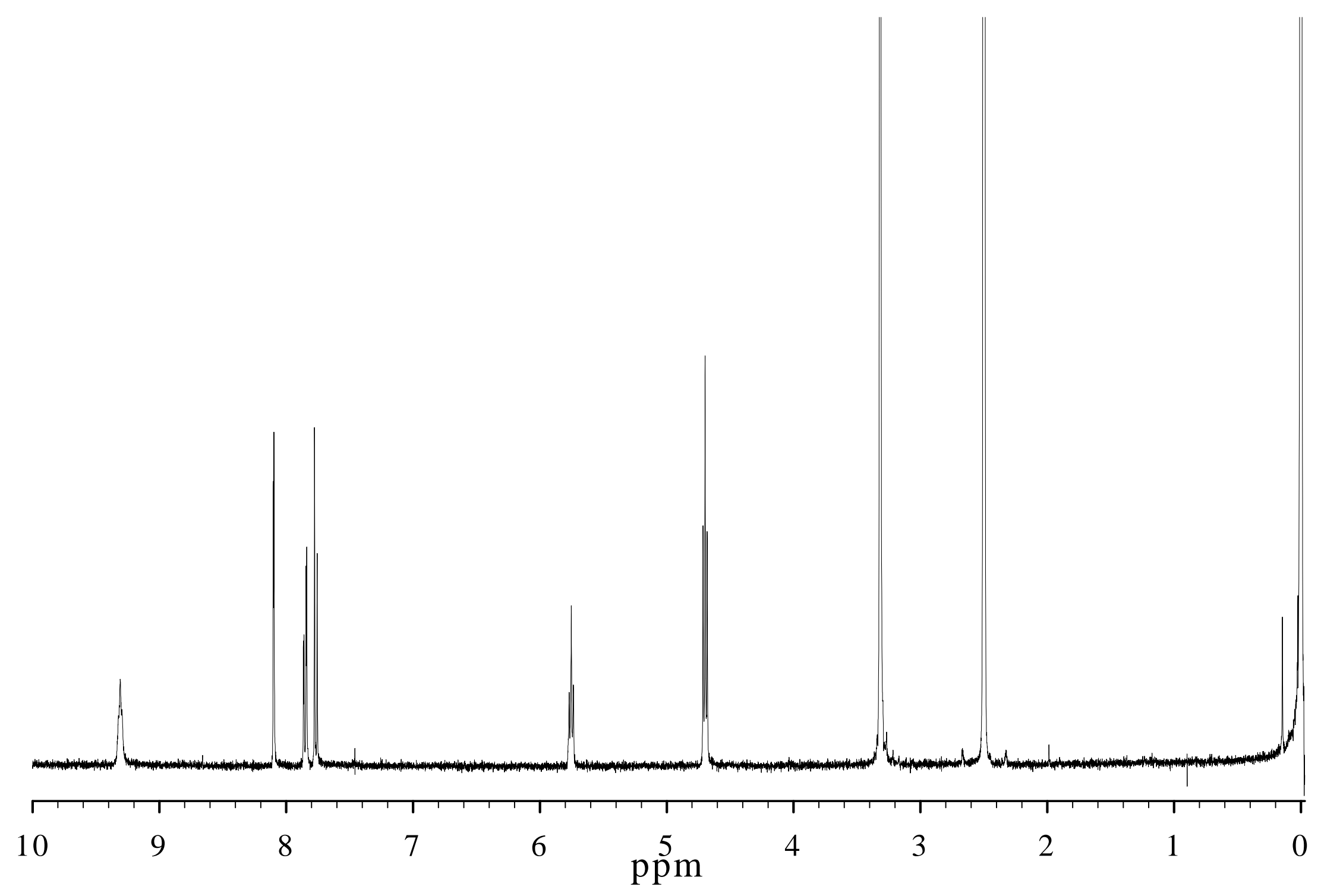

Figure 6S: $\quad{ }^{1} \mathrm{H}-\mathrm{NMR}$ of 3,4-dichloro- $N$-(hydroxymethyl)benzamide in DMSO at $25^{\circ} \mathrm{C}$ using $400 \mathrm{MHz}$ spectrometer. 


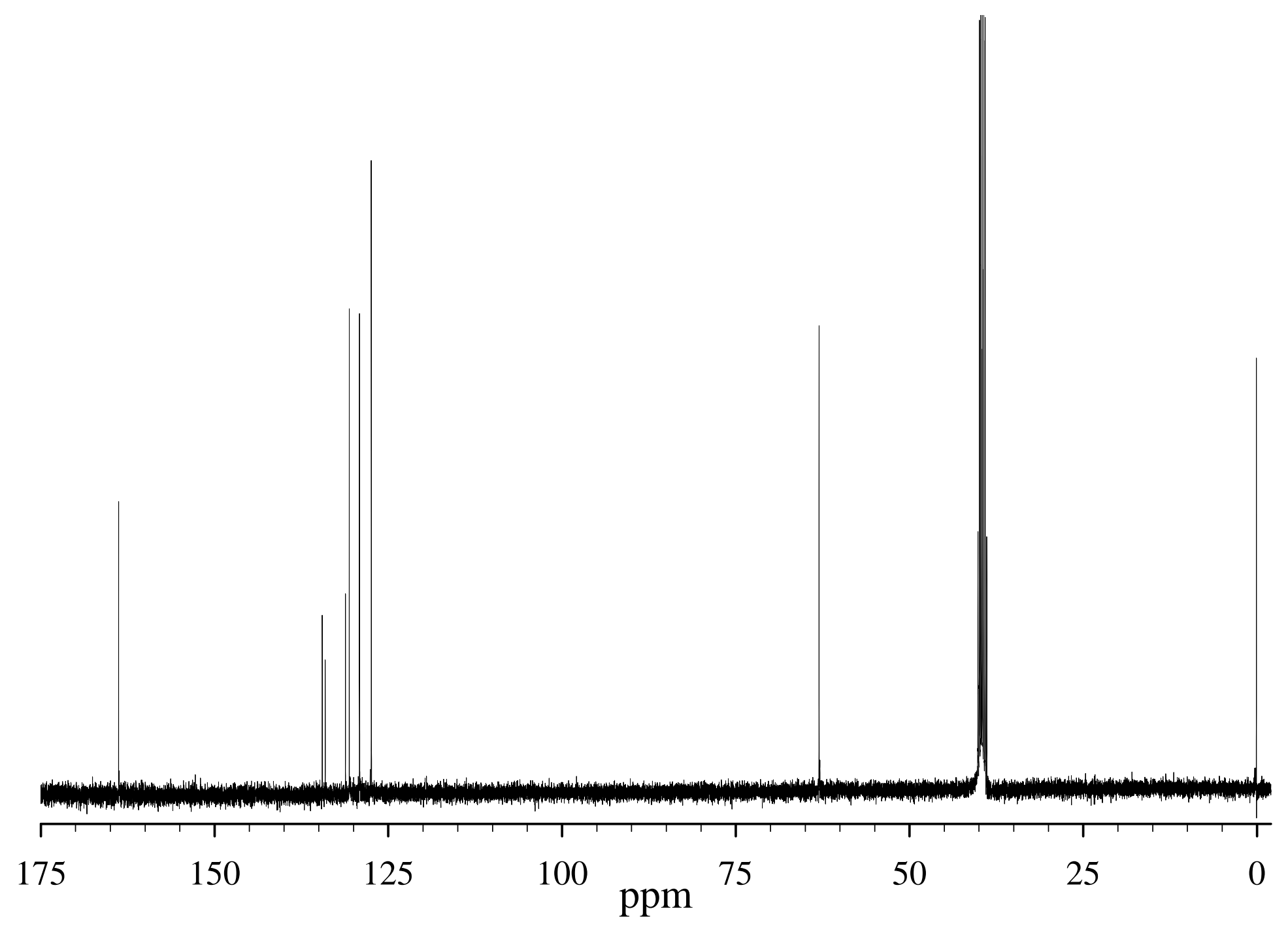

Figure 7S: $\quad{ }^{13} \mathrm{C}$-NMR of 3,4-dichloro- $N$-(hydroxymethyl)benzamide in DMSO at $25{ }^{\circ} \mathrm{C}$ at $100 \mathrm{MHz}$. 


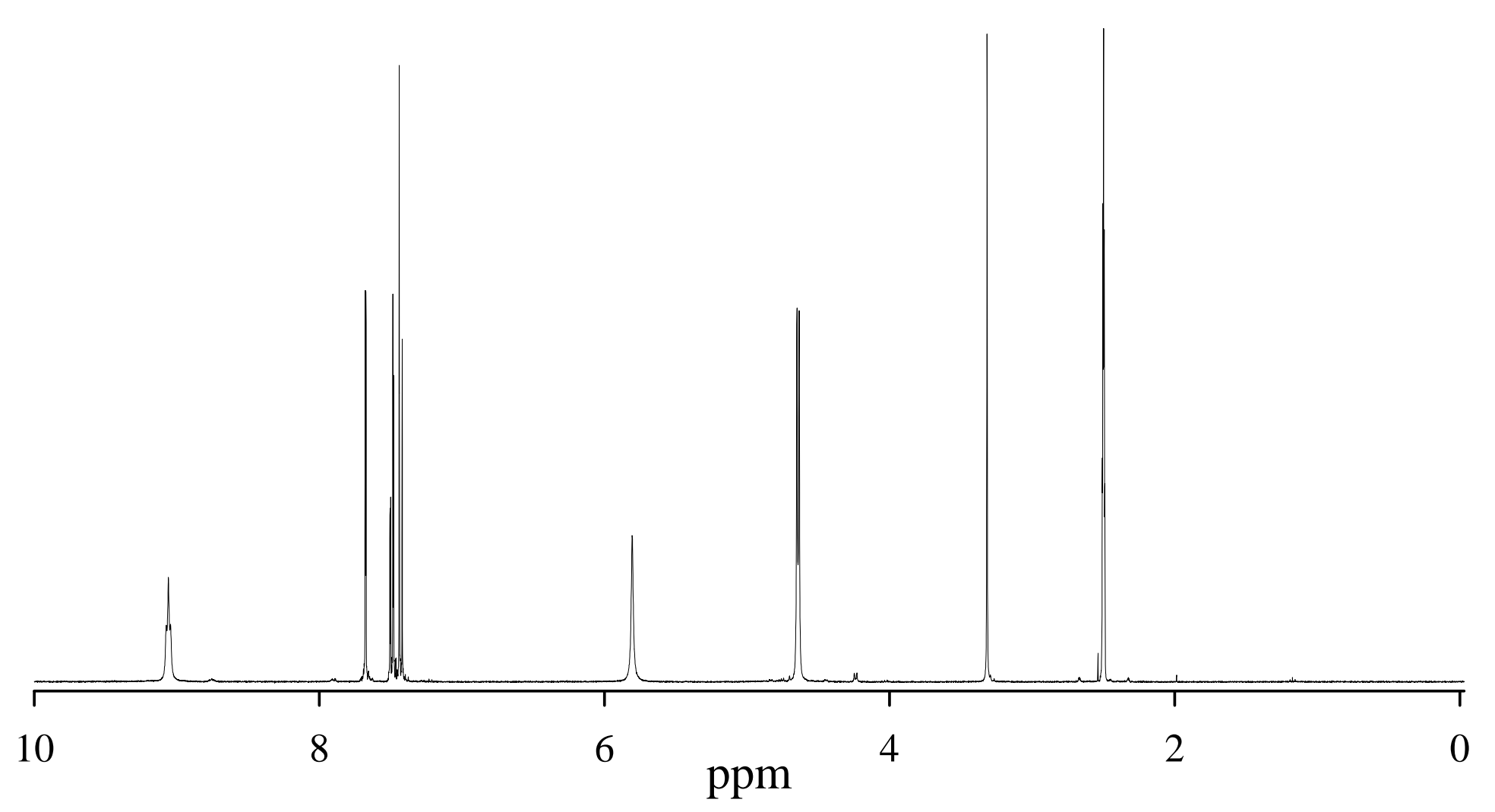

Figure 8S: $\quad{ }^{1} \mathrm{H}-\mathrm{NMR}$ of 2,4-dichloro- $N$-(hydroxymethyl)benzamide in DMSO at $25^{\circ} \mathrm{C}$ using $400 \mathrm{MHz}$ spectrometer. 


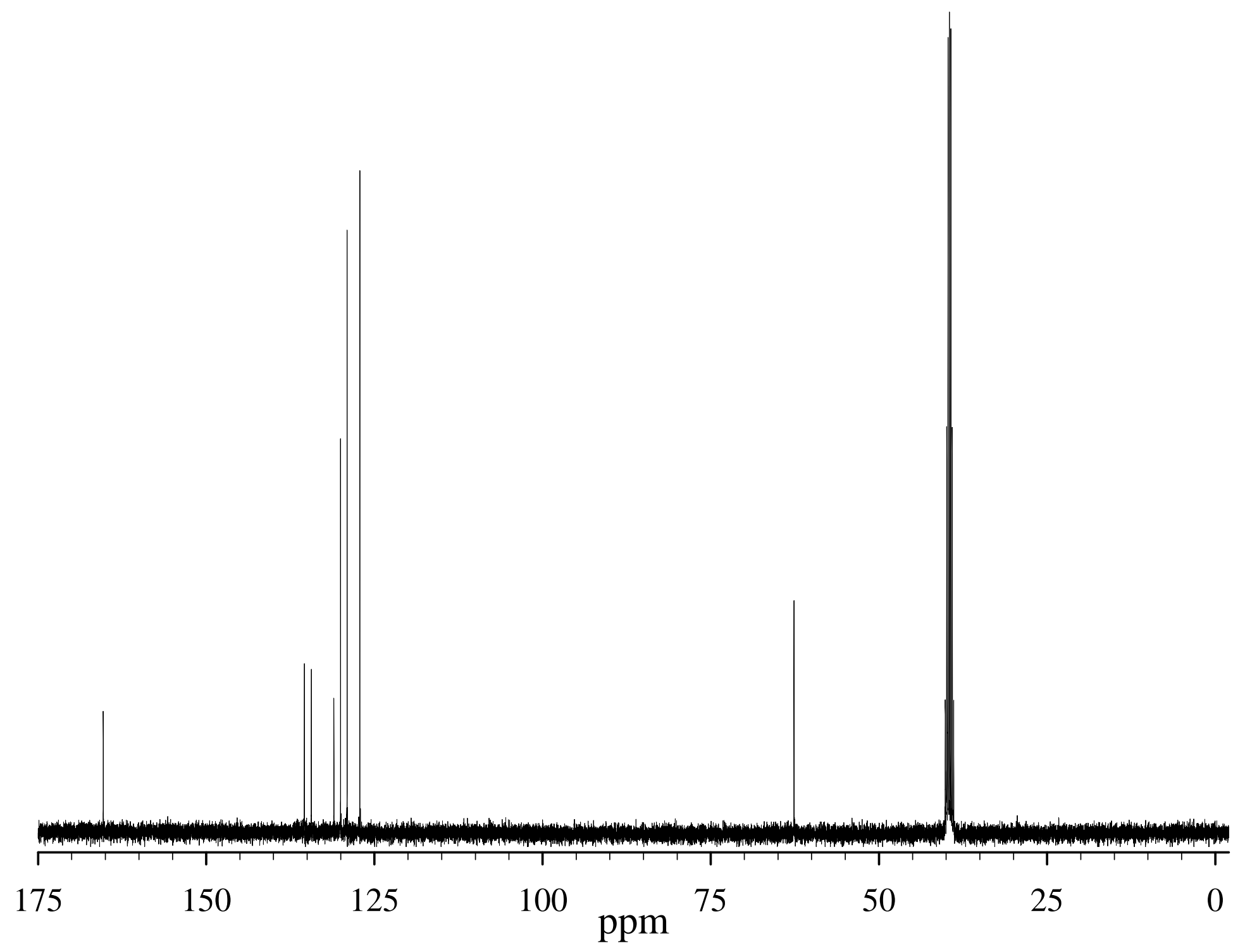

Figure 9S: $\quad{ }^{13} \mathrm{C}$-NMR of 2,4-dichloro- $N$-(hydroxymethyl)benzamide in DMSO at $25^{\circ} \mathrm{C}$ at $100 \mathrm{MHz}$. 